\title{
Transformation of Chinese Tourist Consumer Behavior as a consequence of the COVID-19 Pandemic
}

\author{
Maltseva Yu.A.* Li Henan. \\ First President of Russia Boris Yeltsin Ural Federal University, Ekaterinburg 620002, Russia \\ ${ }^{*}$ Corresponding author. Email: i.a.maltceva@urfu.ru
}

\begin{abstract}
The paper examines changes in consumer preferences and psychology of Chinese travelers, determined by the COVID-19 pandemic and driven by both "COVID stress syndrome" and adaptation to changes and an attempt to establish a lost sense of rational control, and provides expert assessments of consumer behavior trends of Chinese tourists and anxiety triggers, It shows the limitations of consumer behavior and purchase decision making models to explain consumer behavior in offline and online environment and with "COVID-stress syndrome" and substantiates the need to create a comprehensive methodological tool for analyzing and evaluating consumer behavior and purchase decision-making process that takes into account both external marketing drivers and alarm triggers and studies of a new type of consumer - sollicitus homo or person of alarm.
\end{abstract}

Keywords: consumer behavior, Chinese travel services, consumer psychology, consumer behavior patterns,

"COVID stress syndrome", Chinese travelers' anxiety triggers

\section{INTRODUCTION}

Theoretical and empirical studies conducted around the world show that the pandemic has radically changed psychology and consumer habits. Vesti.ru quotes A.Yao, senior economist for developing countries in Asia in AXA Investment Managers: "Of particular concern is the household sector, where voluntary social distancing and labor market turmoil can constrain people's spending on restaurants, movies, travel and other things that require human interaction" [1].

At the same time, it should be noted that classical models of consumer behavior are not sufficiently effective in a situation, when not only economic, political, and other inhibitors, but also fears determined by the "reptilian brain" collide with marketing incentives in the "black box" of consumer consciousness.

The "reptile brain" - also called the first brain, the "crocodile brain" - is responsible for human survival and determines responses to threats, offering two possible options: "hit" and "run" or aggression and retreat. The root trigger for these reactions was the COVID-19 pandemic, the consequences of which were triggered by humanspecific triggers of anxiety.

Restrictions on movement, closure of attractions, increased attention to health and safety measures could not but affect the psychology and decision-making process for purchasing tourist services. Researchers unanimously note that Chinese travelers are now characterized by increased attention to their health and a large number of triggers of anxiety caused by it.

\section{RESEARCH METHODS}

Consumer behavior issues have been and are the focus of many branches of social and humanitarian knowledge. In the works of M. Weber, H. Weblen, R. Bagozzi, G. Bloomer, H. Leibenstein, E. Newman, E. Rogers, T. Folomeeva and other researchers considered consumer behavior from the point of view of formation and development of needs, transformation of needs into demand.

Classical models of consumer behavior and the purchasing decision-making process are presented by such authors as I. Alyoshina, R. Blackwell and others. F. Cotler, F. Nicosia, J. Angel et al. The models of consumer behavior in the Internet environment were reflected in the works of Yu. Loginov, R. Stanislavsky, L. Chonga, N. Shevchenko, H. Shymanski.

Psychological mechanisms based on cognitive distortions and the nuances of consumer behavior are devoted to the work of F. Barden, D. Caneman, R. Thaler, A. Tverski. Problems of individual anxiety and protective mechanisms are considered in the research works of representatives of different directions of psychology - A. Adler, V. Zhurbin, F. Perls, R. Plutchik, K. Rogers, H. Sullivan, L. Slavina, S. Taylor, Z. Freud, A. Freud, K. Horney and others.

The information and empirical basis of the work was formed by author's empirical studies, materials of specialized Russian and foreign Internet resources, as well as statistical data of the National Tourism Bureau of China, empirical data of the Centre for Tourism Research of the Chinese Academy of Social Sciences (CASSTRC) and "CTRIP" company. 


\section{RESEARCH RESULTS}

On 31 December 2019, the World Health Organization was informed by Chinese services of the discovery of pneumonia caused by an unknown pathogen in Wuhan City, Hubei Province. WHO declared an international public-health emergency on 30 January 2020, and on 28 February 2020 raised the global risk assessment from high to very high, with the epidemic declared a pandemic on 11 March 2020 [2].

Due to the COVID-19 pandemic in China, the sale of tourist products and services was banned from January 24 . In the spring of 2020, the Chinese tourism industry began to gradually resume operations, but the situation is still difficult.

We can state that the COVID-19 pandemic has had quite a serious impact on the psychology and consumer behavior of Chinese travelers. Thus, according to the data presented in the report on tourism demand trends, which was presented by CASSTRC [3] on April 28, 2020, more than a third of the population did not plan to travel this year, with more than $50 \%$ attributing it to a high degree of uncertainty and risk.

Attention is drawn to the fact that the COVID-19 pandemic has changed the preferences of Chinese people in choosing a tourist destination - the popularity of domestic tourism and ecotourism is growing [4]. Thus, according to the official representative of the Ministry of Culture and Tourism of China Shan Ganxin, in the second quarter, the number of tourists who visited the main attractions throughout the country increased by $158.7 \%$ compared to the first three months of 2020, and in the third quarter, the number of visitors to tourist sites reached about $70 \%$ of the figures for 2019 for the same period [5]. The preferences of Chinese tourists have also changed in the choice of the country for outbound tourism. If before the pandemic the three leaders were the USA, Japan, Thailand, then "after" - Thailand, Russia, Japan. It should be noted that Chinese travelers confirm the trend identified by OneTwoTrip analysts in a survey of 1700 users - a more thorough approach to the choice of the country, determined by the epidemiological situation and compliance with sanitary standards by local residents.

Such a situation, in our opinion, is conditioned by a revision of values and increased attention to one's own health and, as a result, an increased level of anxiety, both realistic and neurotic. In the opinion of $\mathrm{Z}$. Freud, both types of anxiety are emotional responses either to real threats and dangers of the outside world or to an internally perceived, uncertain danger. It should be noted that according to Freud there is no clear distinction between realistic and neurotic anxiety, as the latter can take the form of real fear. This assumption and studies by King's College London confirm that living under prolonged quarantine can cause symptoms of post-traumatic stress, depression, anger, and fear (6).

Let us present the TOP of Chinese consumers' anxiety triggers related to travel after the pandemic: high risk of infection due to large crowds of people in tourist facilities - $48.6 \%$ of respondents and poor hygiene of transport, accommodation, and meals - $39.7 \%$ of respondents. It should be noted that according to the results of the global survey of the Chinese population conducted in the precrisis period to identify social fears, none of the abovementioned triggers were included in the TOP 5 fears [7].

It is indicative that among the factors, according to CASSTRC, which influence the choice of travel destination, the greatest increase in percentage points was shown by the so-called "emergency" measures, i.e. measures related to the provision of return home, treatment, etc., as well as the procedure of return of funds and the conditions of insurance during the trip (Table 1). It should be emphasized that in general, the pool of factors influencing the choice of the place of travel to the greatest extent has remained unchanged.

It should be noted that the changes have also affected the communication preferences of travelers from China in terms of the choice of information source. According to the company "CTRIP", in the pre-crisis period, $91.56 \%$ of respondents chose the Internet as a source of information about the tourist service, $54.38 \%$ of acquaintances, and only $21.56 \%$ - a travel agency [8]. According to research by the South China Morning Post during the pandemic in China, as well as worldwide, there was a sharp increase in Internet and online media usage. Compared to 2019, Chinese Internet users spent on average two hours more per day online. The number of users over 40 has also increased. Among the trends of Internet communications researchers note: an increase in the popularity of life industries, video services, and video platforms [9].

The COVID-19 pandemic has "brought" the older generation into the online environment and changed user habits directly related to the travel product. Internet orientation, not only as a source of information and a communication tool, but also as a means of travel during the pandemic, has increased significantly. According to Forbes materials, Chinese offline business started to actively use online technologies [10]. Experts unanimously note the growing popularity of online broadcasts, AR and VR tools, video chats, that is, the active development of Internet tourism. 
Table 1: Factors influencing the choice of travel destination

\begin{tabular}{|c|c|c|c|}
\hline Factors & 2019 & 2020 & Devition \\
\hline Emergency measures & $58.3 \%$ & $68.5 \%$ & $+10.2 \%$ \\
\hline Refund procedure & $39.1 \%$ & $47.5 \%$ & $+8.4 \%$ \\
\hline Travel insurance terms and conditions & $44 \%$ & $51.9 \%$ & $+7.9 \%$ \\
\hline Shopping conditions & $40.7 \%$ & $48 \%$ & $+7.3 \%$ \\
\hline State of residence & $63.8 \%$ & $68.3 \%$ & $+4.5 \%$ \\
\hline State of hygiene & $75.2 \%$ & $79.1 \%$ & $+3.9 \%$ \\
\hline Meals & $64.7 \%$ & $68.5 \%$ & $+3.8 \%$ \\
\hline The customs of the country & $61.9 \%$ & $64.7 \%$ & $+2.8 \%$ \\
\hline Condition of transport & $69.1 \%$ & $71.5 \%$ & $+2.4 \%$ \\
\hline Historical sites & $63.1 \%$ & $64.9 \%$ & $+1.8 \%$ \\
\hline Price & $62.7 \%$ & $64.2 \%$ & $+1.5 \%$ \\
\hline Ensuring social security & $81.2 \%$ & $82.5 \%$ & $+1.3 \%$ \\
\hline Natural Landscape & $77.1 \%$ & $77.4 \%$ & $+0.3 \%$ \\
\hline Popularity & $57.9 \%$ & $55.3 \%$ & $-2.6 \%$ \\
\hline
\end{tabular}

\section{DISCUSSION OF FINDINGS}

Experts of the tourism industry, speaking about the high level of uncertainty of its recovery and development after the pandemic, as well as the prolonged period of return to pre-crisis consumer habits (if possible), record a number of already clearly defined trends in the behavior of Chinese consumers of tourist services:

- the increasing role of ecotourism and local tourism in the surrounding areas;

- small group priority when traveling;

- a choice of short, four-day trips;

- advance booking of a private guide and car;

- increased attention to personal protective equipment and the sanitary and hygienic condition of places of residence;

- development of "cloud tourism" and online services. It should be emphasized that in our opinion, the outlined trends are conditioned, among other things, by the fear for one's life and the struggle for its preservation, i.e. by the work of the "reptile brain", and, on the other hand, by adaptation to changes and an attempt to establish a lost sense of rational control.
Thus, the first studies conducted in China showed that the COVID-19 pandemic and related quarantine measures resulted in increased anxiety, sleep disturbance and depressive symptoms in all population groups. And S. Taylor, on the basis of a study of the adult population of the United States and Canada, even suggested the introduction of the new term "COVID-stress syndrome", interpreting it as a strong fear of catching the infection, fear of social and economic consequences of COVID-19 [11]. This position is shared by researchers of digital trends, who believe that the opportunities provided by the Internet environment can not only increase social distance, the level of atomization of individuals, but also become a kind of basis for neurotic anxiety. It is no coincidence that Western analysts state the transformation of the consumer society into a safe society, which certainly actualizes the need for a comprehensive methodological toolkit for analyzing and evaluating consumer behavior and the process of making purchasing decisions.

It should be noted that, despite the confusion of psychological approaches in the study of consumer behavior, for a long time priority was given to the cognitive paradigm, and only at the end of the 20th century the social psychology of consumer behavior and behavioral economics appeared as fields of knowledge. 
Thus, the classical model of consumer behavior of Blackwell, Miniard and Angela consists of seven stages: awareness of need, search for information, preliminary evaluation of options, purchase, consumption, evaluation of options based on the results of consumption and is an algorithm of the consumer decision making process, taking into account many factors, including motivation, values and lifestyle. Model of "black box" of consumer consciousness, proposed by F. Kotler allows seeing the connection between marketing incentives and the decision made under the influence of socio-psychological inhibitors. In the model of F. Nicosia consumer motivation is seen as a key factor in purchasing decision making. However, we emphasize that these models do not take into account changes in consumer behavior due to digitalization, i.e. can only partially be used to explain consumer behavior online and with "COVID stress syndrome".

Within the Electronic consumer decision process model (eCDP), regardless of the outcome of the "awareness of need" stage, the consumer consistently goes through the search, evaluation of alternatives before buying, and the purchase itself. This model is characterized by the reduction and shift of stages due to the specificity of the virtual space, which makes it difficult to track the entire consumer path from the moment the need arises. Citrine's conceptual model correlates consumer behavior in the Internet environment with the degree of innovation. According to the "Research Online / Purchase Offline" (ROPO) model: people more and more actively, more often and thoroughly study offers on the Internet, compare and only then make a decision about buying. It should be emphasized that offline models also do not take into account changes in consumer behavior due to anxiety triggers.

Sharing the position of T.V. Folomeeva emphasizes that consumer choice is the perception and experience of a special social situation of consumption, and therefore modern models of consumer behavior should take into account not only the environment in which the decision to buy and the purchase itself, but also the state of uncertainty and a fundamental change (and sometimes breaking) of the way of life as a consequence of COVID19, generating alarming states. Therefore, marketers need to recognize the emergence of a new type of consumer sollicitus homo or person of concern.

\section{CONCLUSION}

To sum up, the emergence and use of new technologies in the Chinese travel industry, the growth of the segment of consumers who prefer online travel and the active exchange of customer experience in Witchat and QQ, microblogging and travel sites of China, including sites for communication, directly lead to both significant changes in consumer behavior and changes in marketing drivers.

The above gives us grounds to assume that institutional approaches to explaining consumer motivations through the prism of the principles of reasonableness are losing their effectiveness in conditions of economic and social uncertainty. Moreover, the consumer behavior models offered by marketers, usually developed for offline environments, can only be applied to some extent to characterize and describe the consumer behavior of "cloud tourists". While the models of consumer behavior in the Internet environment are limited in explaining the consumer path of consumers who prefer the traditional tourism format but receive information from the Internet environment. We emphasize that neither classical models nor models of consumer behavior in an offline environment take into account the survival mode ( $\mathrm{J}$. Garcia), into which consumers have moved.

At the same time, it should be emphasized that the pandemic and practices of recovery of the tourism industry in China, including trends in consumer behavior, actualize the need for theoretical development and practical testing of complex models of consumer behavior, taking into account both external stimuli offline and online environment, and internal, such as triggers of anxiety or "stress syndrome COVID-19".

We believe that a comprehensive assessment of factors influencing consumer decision making, taking into account individual differences between consumers, including the level of subjective anxiety, will help to select relevant tools for building long-term relationships with them.

\section{REFERENCES}

[1] The pandemic has changed the priorities of Chinese consumers.

https://www.vesti.ru/finance/article/2405889

[2] WHO | Pneumonia of unknown etiology - China. URL: https://www.who.int/csr/don/05-january-2020pneumonia-of-unkown-cause-china/en/

[3] World Travel \& Tourism Council (WTTC). https://wttc.org/

[4] Chinese experts explain how tourism will go after the pandemic | Russian news. - URL:

https://news.ru/asia/kitajskie-eksperty-obyasnili-kakimputem-pojdet-turizm-posle-pandemii/.

[5] China copes without us: how will the prices for vacations change after the opening of the borders? | profi.travel. - URL:

https://profi.travel/news/48173/details.

[6] New challenge for China: psychological problems as a consequence of the COVID-19 pandemic / ekd.me. - URL: https://ekd.me/2020/04/novyj-vyzov-dlyakitaya-psixologicheskie-problemy-kak-sledstvieepidemii-covid-19. 
[7] Chinese: 5 biggest fears.

http://www.chinamodern.ru/?p=13678

[8] Home_iresearch.

http://report.iresearch.cn/report_pdf.aspx?id=3225

[9] China Internet Report 2020: How the pandemic and trade war with the United States played into the hands of technology in China. https://ekd.me/2020/07/chinainternet-report-2020-kak-pandemiya-i-torgovaya-vojnas-ssha-sygrala-na-ruku-texnologiyam-v-kitae/

[10] The crown was lifted: how the virus changed consumer habits in China, Forbes.

https://yandex.ru/turbo/forbes.ru/s/forbeslife/.

[11] The horror of the invisible How the pandemic affects the psyche.

https://iq.hse.ru/news/366225935.html [12] Ph. Kotler, Customer Value Management, J. of Creating Value, Management Review 6 (2018) 9-12.

[13] R.C.Y.Chang, J. Kivela, A.H.N.Mak, Food preferences of Chinese tourists, Annals of Tourism Research 37(4) (2020) 989-1011. DOI:

https://doi.org/10.1016/j.annals.2010.03.007

[14] F. Kock, A. Norfelt, A. Josiassen, A.G. Assaf, M.G. Tsionas, Understanding the COVID-19 tourist psyche: The Evolutionary Tourism Paradigm, Annals of Tourism Research 85 (2020). DOI:

https://doi.org/10.1016/j.annals.2020\&103053 